\title{
The Effect Of Collaborative Writing Technique Through Students' Writing Announcement Text At Second Grade In Smp N 3 Bonjol
}

\author{
Nova Syafitry; Absharini Kardena \\ Institute Agama Islam Negeri Bukittinggi \\ novasyafitry4@gmail.com \\ absharinikardena@yahoo.co.id
}

\begin{abstract}
This research was due to discover the effect of collaborative writing technique through students' writing announcement at second grade in SMP N 3 BONJOL because some of students in SMP N 3 BONJOL still had problems in master english especially in writing text. Some of the students had a problems in making paragraph clearly, in organizing their ideas, to found their grammatical or vocabulary error and etc. The research used experimental research, the researcher used quasi experimental design by using pretestposttest design. The data was through pre-test and post-test to experimental and control class. To analyze the data, the researcher used the normality by using lilifors test and the homogenity test by using $\mathrm{F}$ test and to test the hypothesis the researcher used t-test formula and consulted the result into t-table with level of significant $\alpha=0.05$. From the result and accounting the pretest and posttest scores of experimental class, it was found using collaborative writing technique in writing had better result than using conventional technique.
\end{abstract}

Keyword: Writing, Collaborative writing technique

\section{INTRODUCTION}

Writing is an active human imagination or mind which always think of new things in moving the ideas in written expression. Writing is one of the skills in english. According to Harmer, writing in the language classroom is often seen as an extension of on support for the other skills. the purpose of the teaching of writing is to enable english foreign language students to master functional and monologue text in the form of genres such as descriptive, narrative, recount, procedure, and report.

Based on the researcher observation at SMP N 3 BONJOL, the students were not interest and looked bored in english class, some of them noisy, and did another activity, rather than paid attention and explenation to the teacher. Besides, the students were also passively involved in teaching and learning process. The researcher found various kinds of problems confront by the students in making a 
announcement text. The students explained that they were not able to make a announcement text in English for various reasons that, the students have a lack of vocabulary and the students have a limited ideas to make the announcement text.

In SMPN 3 BONJOL the students are required to be able to make and understand the announcement text, it contained in the sub indicators of learning this material. Meanwhile, students are still unable to make the announcement text. For the argument above, it can be said that influence the students announcement text mastery are the teacher and the students. The students should be brief and could answer what, when, where, and who. Often it includes why and how. It seems that it is easy to make announcement, but most of students always feel difficult when they are asked to make their own, and the students achievement is not only affected by their ability and skills in writing. But also influenced by the method which is used. Some teacher taught writing just gave explanation and exercises. It makes students less comprehended, less interest in writing, and makes students did not to continue the learning process.

\section{METHODS}

This research used descriptive quantitative method. Descriptive quantitative research rfers the simantic phenomenom via statistical, mathematical or numerical. It means that experimental research is the research which tries to observed the cause effect relationship. This research was used two groups as sample. The experimental class was treated by applying Collaborative Writing strategy and the same English writing material in teaching writing.

The population of this research was all of the second grade students (VIII class) at SMP N 3 BONJOL. The researcher use test as the instrument of the research. In this research, the researcher gave the pre test and post test to identify the effect of collaborative writing technique on students writing skill. The test will set based on the goal of teaching and learning that would be achieve. The pretest use to know the students' writing ability at the beginning and posttest use to know the development of the students' writing ability after aplly collaborative writing in teaching writing.

\section{FINDING AND DISCUSSION}

The researcher describe the result finding in using of collaborative writing technique in writing. The finding includes the using of collaborative writing can improve the students'writing. 
BL'TAL, (ENGLISH JANGUAGE 'TEACHING, APPIIED IINGUIS'IICS

AND II'TIRA'TURI)

Vol. 2 No. 1, 2021

Available online at https:/ /jurnal.iainponorogo.ac.id/index.php/eltall

\section{Description of the Data}

a) Data from the pretest experimental class and control class

The data analysis have been given by the research at the first meeting before conducting the treatment. The pre-test was carried out to identify students ability in writing before they got the treatment.

Table 1.1: Table Scores The result of the Calculation of Scores

\begin{tabular}{|l|l|l|}
\multicolumn{2}{c}{ Gained from the Pre-test } \\
\hline Statistic & Experimental class & Control class \\
\hline $\mathrm{N}$ & 23 & 23 \\
\hline Mean score & 46 & 43 \\
\hline Standard deviation & 6,95 & 6,55 \\
\hline Minimum & 40 & 35 \\
\hline Maximum & 55 & 55 \\
\hline
\end{tabular}

The table 1 ,it shows that the mean of the experimental group pre-test score 46, while the mean of the control group pre-test 43 with a difference of these group's score.

b) Data from the posttest of experimental class and control class

The post-test was done after the treatment in order to find out if there any significant effect of using collaborative writing through students writing. The post-test was given to the experiment and control group after treated. Both group were given the same test material and time allocation

Table 1.2. Table Scores The result of the Calculation of the Score Gained from Post-test

\begin{tabular}{|l|l|l|}
\hline Statistic & Experimental class & Control class \\
\hline $\mathrm{N}$ & 23 & 23 \\
\hline Mean score & 78 & 61 \\
\hline Standard deviation & 8,24 & 11,28 \\
\hline Minimum & 60 & 45 \\
\hline Maximum & 92 & 88 \\
\hline
\end{tabular}

The table 2 above shows that the mean score of the experimental class posttest is 78 , while the mean the score of the post-test score of the control class is 61 . 
BL'TALL (ENGLISH LANGUAGE 'TEACHING, APPIIEI) LINGUISTICS

AND II'TIRA'TURI)

Vol. 2 No. 1, 2021

Available online at https:/ /jurnal.iainponorogo.ac.id/index.php/eltall

It means that the mean score of the experimental class was higher than the control class. The standar deviation of the experimental class is 8,24 and the control class is 11,28 .

.Table 1.3. The comparison of pre-test and post-test of the experimental and the control class

\begin{tabular}{|l|l|l|}
\hline Thest Result & Pre-test & Post-Test \\
\hline \multirow{2}{*}{ Experimental Class } & $\mathrm{S}=6,95$ & $\overline{\mathrm{X}}=78$ \\
& $\mathrm{~S}^{2}=48$ & $\mathrm{~S}=8,24$ \\
& $\overline{\mathrm{X}}=43$ & $\mathrm{~S}^{2}=68$ \\
\hline Control Class & $\mathrm{S}=6,55$ & $\overline{\mathrm{X}}=61$ \\
& $\mathrm{~S}^{2}=41$ & $\mathrm{X}=11,28$ \\
& $\mathrm{~S}^{2}=122,23$ \\
\hline
\end{tabular}

Based on the table 3 above, the post-test result of the experimental class is higher than the pre-test result (78) higher than (46). It means that the treatment that has been used by the researcher can help the students in improving the students' writing. The comparison of the post-test result between experimental and control class showed that the control class test result was lower than experimental class. It is indicated by the mean score of the post-test result of control class ( 61 ) is lower than the experimental post-test result (78). It means that the students who were treated by using collaborative writing give better result than the students who were not taught by using collaborative writing.

\section{Testing hypothesis}

\section{a. The first hypothesis}

Based on the first hypothesis, to find whether Ha is accepted or rejected, the value of the $t$ obtained was compared with the value of $t$-table. If the value of the $t$ obtained is bigger than the value of the $t$-table the descriptive Ha is accepted. However, if the value of $t$ obtained is the same or lessthan the value of t-table, the null hypothesis Ho is accepted. 
Available online at https:/ /jurnal.iainponorogo.ac.id/index.php/eltall

Ha: there is significant effect of using collaborative writing trough students' writing ability

Ho: there is no significant effect of using collaborative writing trough students' writing ability

Then, the calsulation of pre-test and post-test scores of the experimental class were explained bellow:

Table 1.4: The Mean Score, Standar Deviation, variant, and sum square

\begin{tabular}{|l|l|l|l|l|}
\hline The Class & $\begin{array}{l}\text { Mean Score } \\
(\times)\end{array}$ & $\begin{array}{l}\text { Totally of } \\
\text { Sample (N) }\end{array}$ & $\begin{array}{l}\text { Standar } \\
\text { Deviation }\end{array}$ & $\begin{array}{l}\text { Variant } \\
\text { Ss }\end{array}$ \\
\hline $\begin{array}{l}\text { Pre-test } \\
\text { Experimental Class }\end{array}$ & 46 & 23 & 6,95 & 48 \\
\hline $\begin{array}{l}\text { Post-test } \\
\text { Experimental Class }\end{array}$ & 78 & 23 & 8,24 & 68 \\
\hline
\end{tabular}

$\mathrm{t}=\frac{\bar{x} 1-\bar{x} 2}{\sqrt{\frac{s_{1}^{2}}{n 1}+\frac{S 2^{2}}{n 2}}}$

$$
\mathrm{t}=\frac{32}{\sqrt{0,30}}
$$

$\mathrm{t}=\frac{78-46}{\sqrt{\frac{48^{2}}{23}+\frac{68^{2}}{23}}}$

$$
\mathrm{t}=\frac{32}{0,54}
$$

$$
\mathrm{t}=\frac{32}{\sqrt{\frac{2,304}{23}+\frac{4,624}{23}}} \quad \mathrm{t}=\frac{32}{\sqrt{0,10+0,20}}
$$

From the t test above, the mean score of the post-test $(\bar{x} 2)$ is 78 . It was bigger than the mean score of the pre-test $(\bar{x} 1)$ is 46 . It was found that $t$ obtained is 59,25 and the $t$-table for degrees of freedom $(d f)=(n a+n b-2)=$ $(23+23-2)=44$ with level of significance $(\propto) 0.05$ is 1.6802 . Through comparing the $\mathrm{t}$-obtained and the t-table, it can be seen as $-\mathrm{t}$-table $1 / 2^{\propto>t}$ obtained $>$ t-table $1 / 2 \propto$. It can be concluded that there was a significant effect of using collaborative writing technique through students' writing ability in announcement text. 
BLTALL (ENGLISH IANGUAGE 'TEACHING, APPLIED IINGUIS'TICS

AND LI'TIRA'TURE)

Vol. 2 No. 1, 2021

Available online at https:/ /jurnal.iainponorogo.ac.id/index.php/eltall

\section{b. Second hypothesis}

Ha means there are significant difference between using collaborative writing through students' writing announcement text and the students' who do not using collaborative writing with conventional technique through students' writing announcement text. On the other hand, Ho means there are no significant different between using collaborative writing with conventional technique through students' writing announcement text. To measure whether the researcher would accept or reject the hypothesis, the researcher used this formula t-obtained located before $\mathrm{t}$-table $1 / 2 \propto$ and after $-\mathrm{t}-$ table $1 / 2 \propto$, it means that Ha accepted and $\mathrm{H}_{\mathrm{o}}$ rejected (-t-table $1 / 2 \propto>\mathrm{t}$-obtained $>\mathrm{t}$-table $1 / 2 \propto$ ) as explanation below:

\begin{tabular}{|l|l|l|l|l|}
\hline The Class & $\begin{array}{l}\text { Mean } \\
\text { Score }(\mathbf{x})\end{array}$ & $\begin{array}{l}\text { Totally of } \\
\text { Sample } \\
\text { (N) }\end{array}$ & $\begin{array}{l}\text { Standar } \\
\text { Deviation }\end{array}$ & $\begin{array}{l}\text { Variant } \\
\mathbf{S}^{\mathbf{s}}\end{array}$ \\
\hline $\begin{array}{l}\text { Post-test } \\
\text { Experimental Class }\end{array}$ & $\mathbf{7 8}$ & $\mathbf{2 3}$ & $\mathbf{6 , 9 5}$ & $\mathbf{4 8}$ \\
\hline Post-test & $\mathbf{6 1}$ & $\mathbf{2 3}$ & $\mathbf{1 1 , 2 8}$ & $\mathbf{1 2 7 , 2 3}$ \\
\hline Control Class & & & & \\
\hline
\end{tabular}

Table1.5: The Mean Score, Standar Deviation, variant, and sum square

$$
\begin{array}{ll}
\mathrm{t}=\frac{\bar{x} 1-\bar{x} 2}{\sqrt{\frac{S 1^{2}}{n 1}+\frac{S 2^{2}}{n 2}}} & \mathrm{t}=\frac{17}{\sqrt{0,803}} \\
\mathrm{t}=\frac{78-61}{\sqrt{\frac{48^{2}}{23}+\frac{127,23^{2}}{23}}} \quad \mathrm{t}=\frac{17}{0,89} & \mathrm{t}=\mathbf{1 9 , 1 0} \\
\mathrm{t}=\frac{17}{\sqrt{\frac{2,304}{23}+\frac{16,187}{23}}} &
\end{array}
$$

From the calculation of post-test score of the experimental and control classes, the mean score of the post-test in experimental class ( $\bar{x} 1)$ is 78. It is greater than the mean score of the post-test in control class ( $\bar{x} 2) 61$. 
BLTALL (ENGLISH IANGUAGE 'TEACHING, APPLIED IINGUIS'TICS

AND II'TIRA'TURI)

Vol. 2 No. 1, 2021

Available online at https:/ /jurnal.iainponorogo.ac.id/index.php/eltall

Then, the standard deviation of each class is obtained and they are analyzed by using t-formula to find the value of t-obtained. It is found that t-obtained is $\mathbf{1 9 , 1 0}$ and the $\mathrm{t}$-table for degrees of freedom $(\mathrm{df})=(\mathrm{na}+\mathrm{nb}-2)=(23+23$ - 2) = 44 with level of significance $(\propto) 0.05$ is 1.6082 Through comparing the t-obtained and the $\mathrm{t}$-table, it can be seen as $-\mathrm{t}$-table $1 / 2 \propto>\mathrm{t}$-obtained $>\mathrm{t}$ table $1 / 2^{\propto}$. It can be concluded that there was a significant difference of using collaborative writing technique through students' writing ability in announcement text.

\section{c. Third hypothesis}

Ha: The use of collaborative writing is better than using conventional technique

Ho: The use of collaborative writing is not better than using conventional technique

The data gotten to prove the hypothesis above is the same with the data of the second hypothesis. The difference occurs in the form of onetailed or two-tailed tests and the third hypothesis in the form for one-tailed test.

\section{The curve of $t$-test result in third hypothesis}

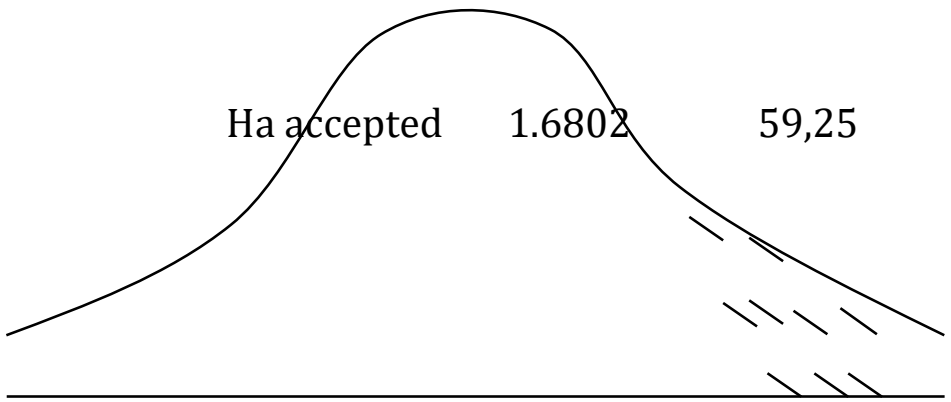

The graphic above is shown that tobtained was higher than $t$ table, 59,25 > 1.6802. It means that the descriptive hypothesis (Ha) was accepted or the null hyphotesis (Ho) was rejected because tobtained was haigher than t table with $(\propto)$ 0.05 (one tail). Hence, it can be concluded that use of collaborative writing is better than using conventional technique in students' writing announcement text.

Based on the finding above, it can be concluded that all null hypothesis were rejected and all alternative hypotheses were accepted. It means collaborative writing technique has a significant effect on students' writing ability and also has a significant difference toward students' writing ability. Last, using collaborative writing technique through students' writing ability was better than without using conventional technique. 


\section{CONCLUSION}

This research was about the effect of using Collaborative Writing technique through students' writing announcement text at second grade in SMP N 3 Bonjol. This section discusses the research finding based on the related study. This research was done by giving the writing test to the students in the experimental class and control classes, the function of the writing test is to see the students' fluency to write English well, the grammar, the vocabulary, the fluency and the form. In order to express their own ideas, feelings based on the topic selected. From the explanation above, it can be conclude that collaborative writing as a technique can improve students writing ability in writing announcement text. Other than that, collaborative writing can also be used as an effective technique to help teacher in teaching.

\section{REFERENCES}

Arifmiboy, Kumpulan Materi Kuliah Statistik, STAIN Sjech Djamil Djambek Bukittinggi, unpublished

Arikunto,Suharsimi, Manajemen Penelitian, Jakarta:Rineka Cipta, 2006

Arapof, Nancy, Writing: A Thinking Process, TESOL QUARTELY,1967

Brown, H. Doughles, Teaching by Principle: an Interactive Approach to Language Pedagogy, San Frasnsisco State University Longman,2001

Charles,J,Assessing Writing, Cambridge Unniversity Press, 2002

E George ,Wishon, Lets Write English,Litton Educational Publishing, 1980

F Lyle, Bachman, Statistical Analysis for Language Assessment, The Edinburgh Building, Cambridge, 2004

Folse, S Keith, Great Essay, Houghton Mifflin Company, 1999

Gustira, Irvonny, Eliza, and Febria Sri Artika. An Analysis of Syntactic Structures and Error on the Relative Clause as Found in Students' Academic Writing at the Sixth Semester Students of English Department. Advances in Social Science, Education and Humanities Research. vol 411

Henita, Astutu, Absharini Kardena, Eliza, Students' Difficulties In Translating Narrative Text From English Into Indonesia At Iain Bukittinggi. Volume 6, Number 1, June 2020 
Lismay, Leli, Logical Fallacies on Students Argumentative Writing. Journal of English Language Pedagogy. Vol 5, No 02, July 2020

Reflinda. Enhancing Academic Writing ability for Higher Education Students. VISION Vol 10 No. 10 Juli - Desember 2016 ISSN: 2086-4213

Syahrul, Widya Syafitri, An Analysis Of Students' Anxiety In Academic Writing At Sixth Semester Students Of English Education Department In Iain Bukittingi Academic Year 2017/2018. EDUCATIVE JOURNAL: Journal of Educational Studies. Vol 1, No 01, December 2018 